\title{
University Impact on Regional Development in the Context of Smart Specialisation
}

\author{
YeVHeniIA POLISHCHUK \\ ANNA KORNYLIUK \\ Alla IVASHCHENKO \\ Corporate Finance Department, \\ Kyiv National Economic University named after Vadym Hetman \\ YURIY DANKO \\ Marketing and Logistics Department, \\ Sumy National Agrarian University

\section{Oleh Pasko} \\ Research Coordination Office, \\ Sumy National Agrarian University
}




\begin{abstract}
Regional development on the basis of smart specialisation entails the involvement of stakeholders in innovation processes such as business, public organisations, localgovernment and academic sectors. Universities are the drivers of a region's development because they have a broad research base. Using the methodology of the Joint Research Centre (European Commission), the impact of Sumy National Agrarian University on the development of the Sumy Region was assessed by such criteria as its cooperation with stakeholders, innovative infrastructure of the university, development of academic entrepreneurship, and its role in developing the region. The method of collecting qualitative data involved conducting structured interviews with the university administration and relevant departments. The collected data were analysed by content analysis. As a result of testing the methodology, its high level of applicability was noted in the Ukrainian academic space, outside the EU. It is recommended to use the method of assessing the impact of the university on the development of the region during the entrepreneurial discovery process, which follows the definition of priorities for the development of the region in the context of smart specialisation. The recommendations were given on the revival of cooperation with stakeholders, possible ways of developing academic entrepreneurship and building innovation infrastructure. The results of the research presented in this article may be used in university promotion within the region and the country as well in the context of smart specialisation. Policy makers may use the research results in order to provide regional innovation policy.
\end{abstract}

Keywords: university, regional development, smart specialisation, SMEs

JEL Classification Codes: I23, O31, O32, R11

\title{
Introduction
}

The intensification of innovation processes in different regions leads to an increase in their competitive position not only at the national level but also in the global dimension. However, the innovation ecosystem of domestic regions needs significant development, as evidenced by the negative dynamics of Ukraine's rating position in the Bloomberg Innovation Development Index: in 2019 Ukraine ranked $53^{\text {rd }}$ in the world (for comparison: in 2018 it ranked $46^{\text {th }}$ ). This indicates problems in research and innovation.

We believe that the introduction of the smart specialisation approach of the regions can intensify their innovative development. In the process of smart specialisation, the interaction of four groups of stakeholders is envisaged: regional public authorities, business, public organisations, and scientific and educational institutions. It is the last group of stakeholders that our research focuses on, as the growth of innovation potential can be successfully ensured by the effective functioning of research bases of higher education institutions. 
The purpose of the paper is to study the impact of the university on the development of the regional innovation ecosystem on the example of Sumy National Agrarian University (hereinafter SNAU).

The purpose of the study is reached through answers to the following research questions:

- What is the role of the university in the development of the region?

- How is cooperation with stakeholders carried out?

- What is the innovative infrastructure of the university?

- How does the university develop academic entrepreneurship?

\section{Literature review}

The literature on the role of the university in the development of a certain region has emphasised the importance of stakeholders' communication. The first serious discussions and analysis of the university in regional development emerged during the 1990s (Mertin, 1994; Forbes, 1994; Pires \& Castro, 1997). Since the 1990s the scientific interest to the issues of regional development and universities' impact has grown.

Some scholars explored how regional universities follow the Sustainable Development Goals, SDG (for instance, Purcell Henriksen \& Sprengler, 2020). In these frames they studied the way of learning (including cross-disciplinary perspectives) and types of collaboration with local communities (Wooltorton et al., 2011). Due to the SDG, regional universities paid attention to the entrepreneurial development (Bratucu et al., 2020), manufactural development in China (Jiang et al., 2020; Xia, Li \& Yin, 2020; Ma et al., 2020). At the same time, sustainable development poses a challenge to the regional universities in Finland (Lattu \& Cai, 2020). Some studies are devoted to the exploration of social responsibility for regional development in some African countries (Mbah \& Charles, 2019; Fiarmonti, 2013; Fongwa \& WangengeOuma, 2015). Different practices of a Brasilian university in the frame of regional development were examined on planning social and environmental responsibility (Frandoloso \& Rebelatto, 2019). It was noted that regional management of areas supports actions (integration between the university and the community) directed to the urban sprawl in the nearest territories of a university in Indonesia (Giyarsih, 2017). There are universities regarded as regional hubs for innovatins in Quatar (Salama et al., 2016). Some cases are considered in the context of cooperation between local businesses and universities' laboratories in Slovakia (Vido \& Nalevankova, 2020).

It was also assumed that international students' choice is influenced by the development level of the region where a given university is located (Nichols, 2018). 
Recent evidence suggests that career development of foreign-born immigrants is related to the region where the university they graduated from is placed (Stebleton et al., 2018).

Our previous research has established the relationship between economic development and the government, SMEs and universities' cooperation in the conditions of Industry 4.0. (Antoniuk, 2017). In addition, the link between the market of education and regional development exists (Sozinova et al., 2019).

Most research on the role of the university in regional development focuses on how innovations boost it. Ponsiglione, Quinto, and Zollo (2019) offered an agent-based model of the self-sustaining regional innovation system. The idea of the university as a regional innovative hub is described in the research of Ciapetti (2009) and of Harloe and Perry (2004). Marques et al. (2019) assumed that universities can be regarded as drivers for less developed regions. Chelwa (2020) claimed that nowadays it is impossible to imagine innovative strategies without key roles of the university.

Several studies of regional development have demonstrated the importance of different stakeholders' participation in it (Roman et al., 2020), the so-colled Quadruple Helix Model. This is regarded as a basis for smart specialisation, where four key players are engaged in (the academia, business, local government and civil societies).

A number of authors have considered in their papers universities as main drivers for innovation in different EU countries (Eklinder-Frik et al., 2020; Saha et al., 2020, 2019; Benner, 2020; Dettenhofer, 2019; Tetrevova \& Vickova, 2020; Sardak \& Samoylenko, 2014). A joint research centre has developed under the Regional Innovation Impact Assessment Framework for universities (Jonkers et al., 2018), which is the basis for our research.

Collectively, these studies highlight the need of the university participation in regional development. They outline a critical role of universities in the smart specialisation process as well.

\section{Research methodology}

The methodological basis of the study is an adapted methodology from the Joint Research Centre (European Commission), which is used for reporting and policy development.

The methodology includes 4 blocks: general research of the university; level of cooperation with stakeholders; study of the innovation infrastructure of the university; characteristics of academic entrepreneurship. For more details see Appendix 1. 
The study consisted of three main stages: 1) data collection; 2) data processing; 3) discussion of the results with stakeholders and policymakers and finalisation of the study.

In particular, the method of structured interviews with 15 respondents was used to collect data. The interviews were pre-arranged with the university administration. A working group was set up, consisting of representatives of various departments of the university. The interviews were conducted on the telephone and via mail.

The results of the research were previously presented to the university management. The respondents were given a unique opportunity to be the first to get acquainted with the results of the study, as well as to clarify them. With the help of structured interviews, both quantitative and qualitative data were collected, which made it possible to assess comprehensively the impact of the university on the innovative development of the region. Appendix 1 provides a detailed list of questions in terms of 4 blocks of the methodology that were asked to the respondents during the interviews.

Data processing before the finalisation of the study was carried out by experts in smart specialisation - representatives of the academic sector, policymakers, representatives of business and public organisations.

This technique is also used during the smart specialisation process of regions, which entails active involvement of universities in the innovation ecosystem. This applies to both educational and scientific activities of higher education institutions.

\section{Results}

\section{The role of universities in the regional innovation ecosystem (or development) in the context of smart specialisation (EU case studies)}

Universities are often underestimated and hardly participate in the formation of the innovation vector of national and regional strategies. In addition, the existing paradigm largely ignores the potential contribution of science to regional development and innovation. Therefore, regional investments in the development of university infrastructure to support its main activity (teaching and research) have a significant passive regional multiplier effect even if the university does not actively support regional development.

However, it is clear that universities can play a key role in the social and economic development of their regions, as they can become drivers especially in less favoured regions, where the private sector may be weak or relatively small 
and there are low levels of research. Cases of European universities show that the successful mobilisation of university resources can have a positive impact on the regional economy and the implementation of integrated regional strategies. Thus, universities can play a key role in promoting the development and implementation of Smart Specialization Strategy (S3), strengthening its innovative component and business development. The concept of university impact on the regional ecosystem with areas of cooperation and tools of influence and potential problems of university involvement are presented in Figure 1.

Figure 1. The concept of the impact of universities on the regional ecosystem

\begin{tabular}{|c|c|}
\hline $\begin{array}{l}\text { The role of universities in the } \\
\text { development and implementation of S3 }\end{array}$ & $\begin{array}{l}\text { Problems of university involvement in the } \\
\text { development of the regional ecosystem }\end{array}$ \\
\hline$\downarrow$ & $\downarrow$ \\
\hline $\begin{array}{l}\text { - Assessment of knowledge, capabilities } \\
\text { and competencies of the regions } \\
\text { - Providing global awareness and partnerships } \\
\text { - Specialised research expertise } \\
\text { - Human capital development through } \\
\text { training programmes and courses, advanced } \\
\text { training, consulting services, etc. } \\
\text { - Development of innovations that are closely } \\
\text { related to the research function of the } \\
\text { university } \\
\text { - Promotion of regional capacity building on } \\
\text { the basis of promotionof entrepreneurship } \\
\text { and business development, creating new } \\
\text { businesses, student enterprises, active } \\
\text { cooperation with local business } \\
\text { - Building social dialogue with potential } \\
\text { stakeholders within S3 }\end{array}$ & $\begin{array}{l}\text { - Lack of understanding by top management } \\
\text { of universities of the challenges facing the } \\
\text { regions and representatives of regional } \\
\text { authorities } \\
\text { - The key mission of universities in the region } \\
\text { - Compliance of curricula exclusively with the } \\
\text { needs of students and the national labour } \\
\text { market, while in the local market there is no } \\
\text { clearly defined business demand from local } \\
\text { innovative companies } \\
\text { - Lack of resources in universities to support } \\
\text { regional development where outcomes such } \\
\text { as job creation may go beyond higher } \\
\text { education } \\
\text { - Impossibility of the university to mobilise } \\
\text { their own resources to meet the needs } \\
\text { of the regions within the framework of } \\
\text { national legislation } \\
\text { - Non-acceptance by the business } \\
\text { environment of university developments, } \\
\text { which slows down the demand for them }\end{array}$ \\
\hline $\begin{array}{l}\text { Tools for research activities } \\
\text { of universities to enhance innovation }\end{array}$ & $\begin{array}{l}\text { Tools for universities to promote } \\
\text { entrepreneurship and business development }\end{array}$ \\
\hline$\downarrow \quad \downarrow$ & $\downarrow$ \\
\hline $\begin{array}{l}\text { - Scientific and technological centre } \\
\text { - Science park } \\
\text { - Knowledge transfer partnerships } \\
\text { - Innovative vouchers } \\
\text { - Consulting services }\end{array}$ & $\begin{array}{l}\text { - International relations } \\
\text { - Encouraging the development of intellectual } \\
\text { property } \\
\text { - Development of networks and clusters } \\
\text { - University spin-outs } \\
\text { - Entrepreneurial programmes }\end{array}$ \\
\hline
\end{tabular}

Source: own work. 
The experience of European universities confirms the effectiveness of the proposed tools in Figure 1, such as consulting services can be provided in response to a business request for support for a specific project. The service will be provided in accordance with a clear technical task and will be tied to time with clear milestones and deadlines (case study: Active Technology Transfer, Steiermark Region, Austria).

While innovative vouchers are aimed at stimulating demand for university research rather than meeting existing demand, this can range from solving problems in business operations to discovering innovations in products or services (case study: University of Tartu Institute of Technology, Tartu County, Estonia).

Another effective tool is knowledge transfer partnerships aimed at promoting the mobility of human capital between the university and local businesses (case study: Instituto de Tecnología Cerámica (ITC), Valencia, Spain).

The case of Potsdam University, Brandenburg, Germany, is an example of a successful application of a science park, i.e., a place (physical or even virtual) which is created to become a hub for relevant companies in a particular industry or sector. Science parks can provide services for personnel management, incubation and business support, access to university and other research centre resources, general resources and equipment, as well as soft support such as mentoring, networking, business consulting, and so on. The structure of science parks, supported by different local, regional, national, and European Union funds, may vary and there is no single formula for ownership.

In turn, science and technology parks create a critical mass for business and research innovation, focusing on a specific technology where there is a potentially large global market and significant national potential, which was applied by NanoFab, Venice, Italy.

Entrepreneurial programmes also deserve attention. Universities identify three main thematic areas to support entrepreneurship among students and recent graduates: learning to be entrepreneurial, providing business experience through internships in local SMEs, supporting graduates in setting up new businesses and exploring new business opportunities (case study: Adam Mickiewicz University Foundation, Poznań, Poland).

Spin-out is a term used to describe the process by which staff determines the ability to commercialise elements of a university's research or knowledge base. University spin-outs involve the creation of a new independent enterprise, although they can maintain strong ties with the university which they originated from; a successful case of implementation is the Technoinkubator of the Kraków Technology Park, Poland.

Aalborg University, North Denmark Region, Denmark, develops its own networks and clusters that focus on encouraging and supporting business cooperation, 
institutional development and support in relevant industries. Industries tend to focus on those that offer the greatest potential for economic development at the local level.

Encouraging the development of intellectual property is aimed primarily at ensuring a fair return for the inventor for his/her investment in research and development of new knowledge and technologies by patenting and protecting intellectual property, which is successfully used by the Portuguese Institute of Industrial Property (INPI).

International connections contribute to the development of both the university and business, both in terms of expansion and competitiveness, as well as increase mobility internationally, as evidenced by the experience of Knowledge Economy Skills Scholarships (KESS), Wales, the UK.

Thus, the successful experience of involving European universities in smart specialisation shows the positive impact of universities on the regional ecosystem, so the introduction of European practices in Ukrainian realities to strengthen cooperation between key stakeholders, namely the government, business and academic community can become one of the key areas of regional policy.

Since classically-specialised universities play a crucial role in building regional capacity, the possibility of implementing successful European practices for Ukraine will be analysed on the example of Sumy National Agrarian University (the Sumy Region).

\section{Impact of Sumy National Agrarian University on the regional innovation ecosystem}

\section{General overview and quantitative analysis}

Sumy National Agrarian University (hereinafter SNAU) was chosen to assess the impact on the development of the Sumy Region, as the university administration positions its interest and active participation in local events dedicated to the development of the region's economy. In addition to the modernisation of the research base which was carried out in recent years, the innovative potential in the agricultural sector is realised, which is defined as a direction of smart specialisation of the region.

SNAU, a multidisciplinary higher education institution that conducts innovative educational activities at various levels of higher education, including doctors of philosophy, conducts applied research, is a leading scientific and methodological centre, has a developed infrastructure of educational, scientific and research units, promotes scientific knowledge, and conducts cultural and educational activities.

The university has 8 faculties (the Faculty of Agrotechnology and Natural Resources, the Faculty of Veterinary Medicine, the Faculty of Biology and Technology, the Faculty of Law, the Faculty of Engineering and Technology, the Faculty of 
Food Technology, the Faculty of Economics and Management, the Faculty of Civil Engineering), 1 institute, and 5 colleges.

Quantitative indicators of university development are presented in Figures 1-5.

Figure 1. Budget of Sumy National Agrarian University in 2015-2018, thousand UAH

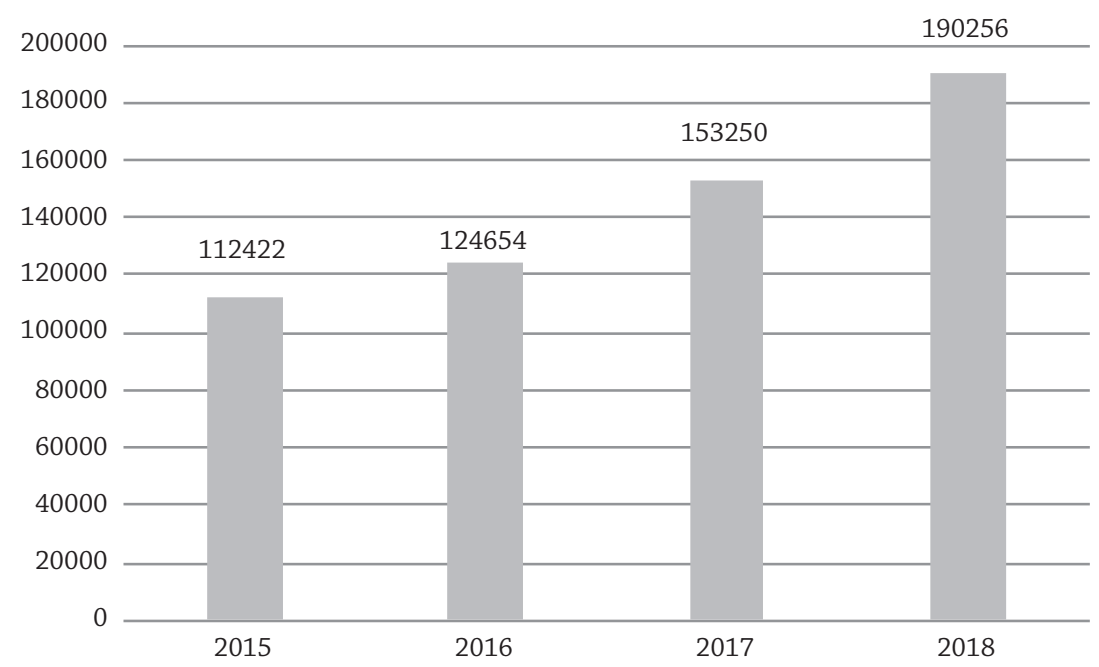

Source: own calculations based on reports of Sumy National Agrarian University (2015, 2016, 2017, 2018).

Figure 2. Number of students at Sumy National Agrarian University in 2015-2019, persons

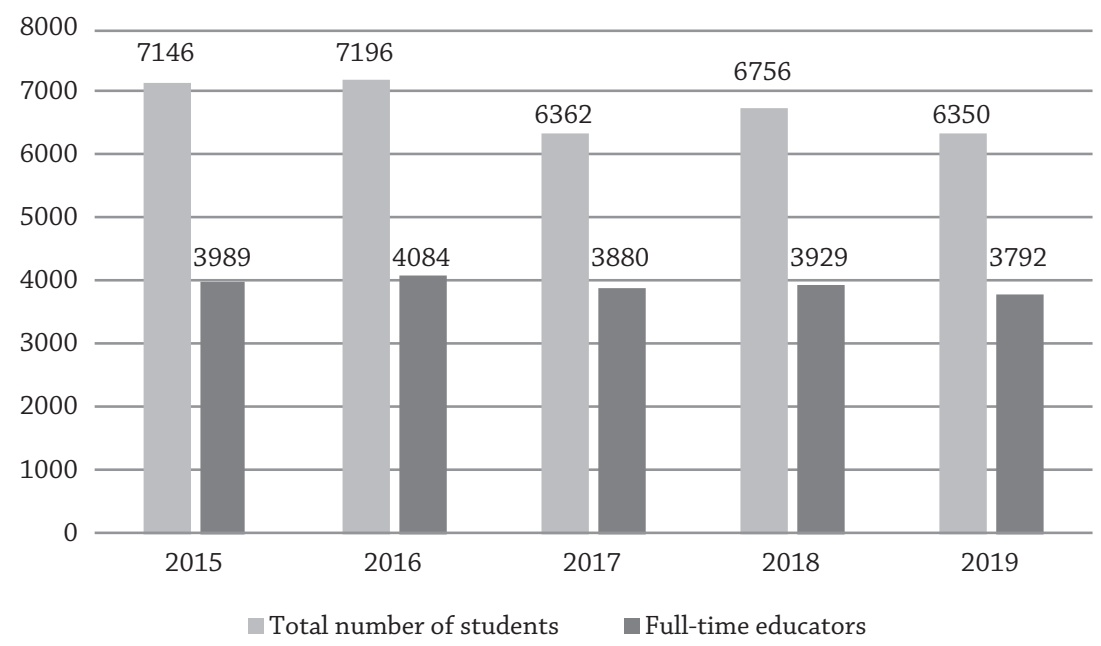

Source: own calculations based on reports of Sumy National Agrarian University $(2015,2016,2017,2018,2019)$. 
Figure 3. The number of foreign students at different educational levels at Sumy National Agrarian University in 2015-2019, persons

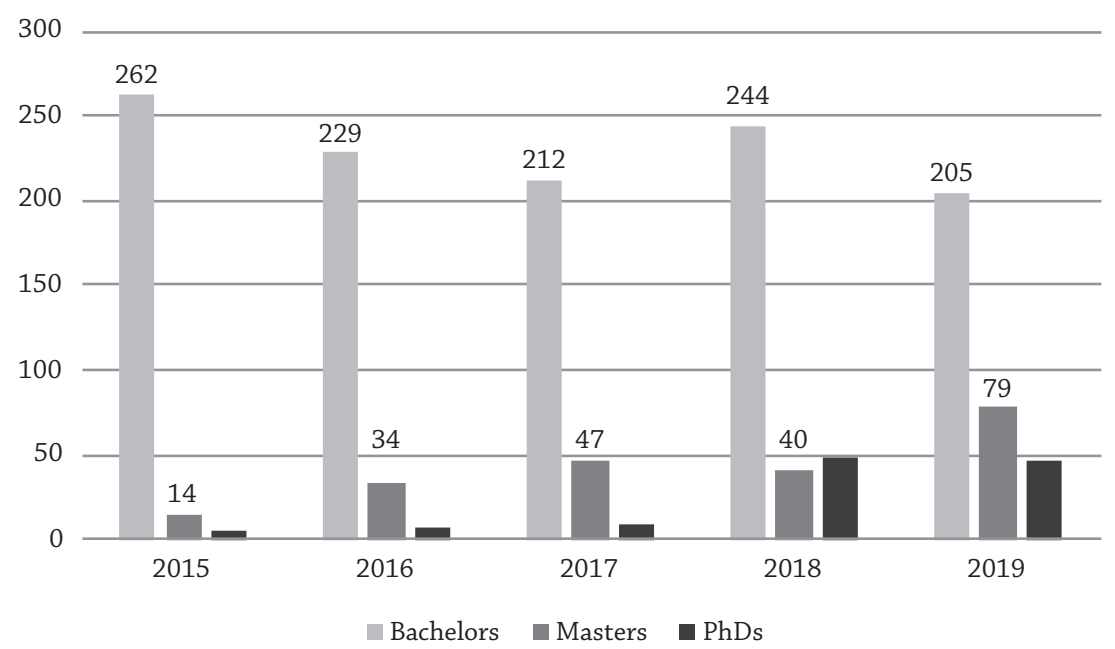

Source: own calculations based on reports of Sumy National Agrarian University (2015, 2016, 2017, 2018, 2019).

Figure 4. Number of researchers of Sumy National Agrarian University in 2015-2019, persons

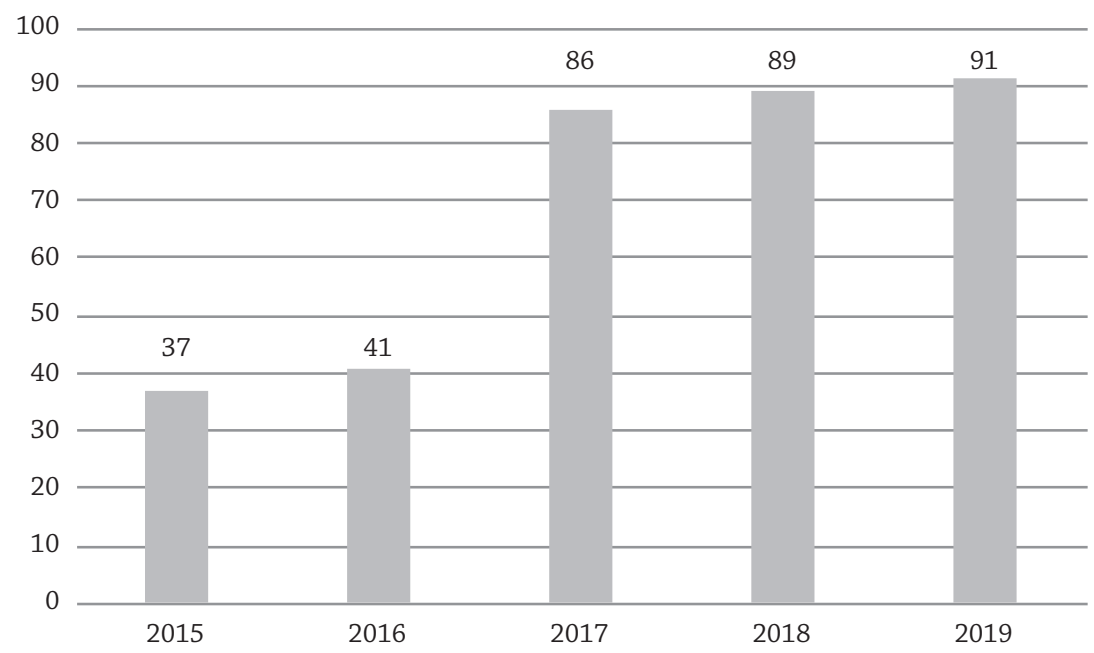

Source: own calculations based on reports of Sumy National Agrarian University (2015, 2016, 2017, 2018, 2019).

In Figure 1 there is a positive dynamics of expenditures for the maintenance of the university and from 2015 to 2018 they increased almost 1.7 times. Figure 2 shows a decrease in the number of students, which generally repeats the national trend and 
SNAU is quite active in attracting foreign students (Figure 3). In addition, over the past two years it has significantly increased the share of foreign students studying at the $\mathrm{PhD}$ level, which means interest in these programmes. Thus, according to the respondents, if in 2017 the share of such students was 5.8\%, then in 2018 and 2019 it increased to $26.3 \%$ and $23 \%$, respectively.

Figure 5. Publication activity of SNAU employees in 2015-2019, units

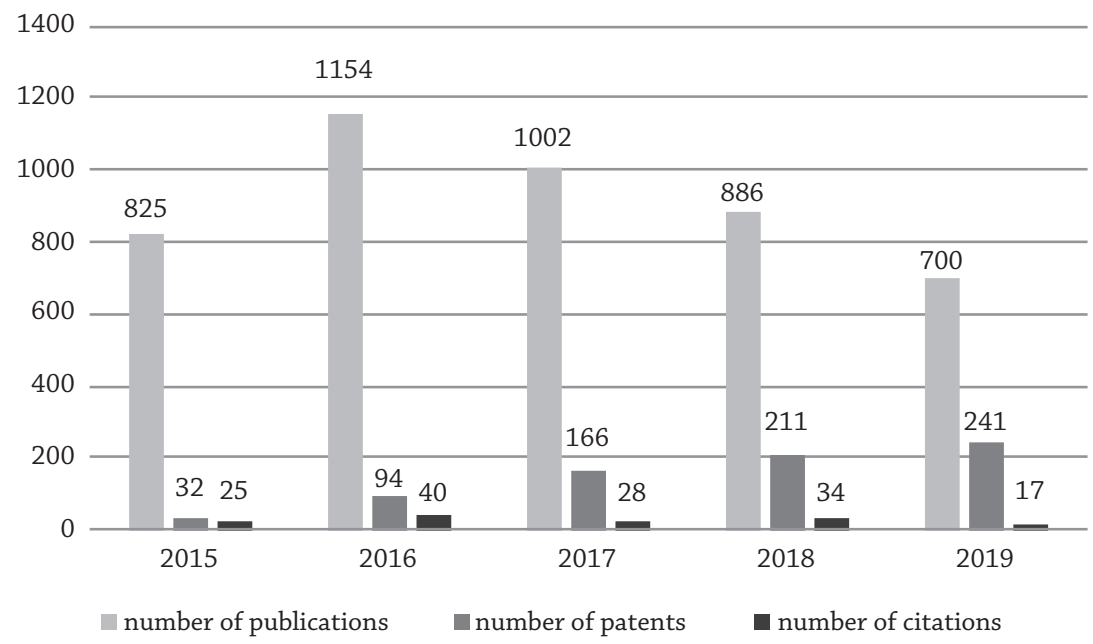

Source: own calculations based on reports of Sumy National Agrarian University $(2015,2016,2017,2018,2019)$.

Regarding Figure 4, it can be assumed that the lack of a positive dynamics of researchers is caused by the national trend of reducing the number of teaching staff. Regarding publishing activity (Figure 5), since 2016 there has been a downward trend in the number of publications. However, according to the respondents, their qualitative component is growing. Publications indexed in scientometric databases are becoming a priority area of publication activity and the number of such publications is increasing year by year. The citations in these publications and the general Hirsh index are also growing rapidly.

The university has the following programmes, which are positioned as unique:

Cynology within specialty 204, Technology of production and processing of livestock products. The uniqueness of this educational programme is that not a large number of free educational institutions in Ukraine train such specialists, plus it combines perfectly well the features of an agricultural university and the interest of the general public, as there are few people who are not fond of dogs.

Precision farming systems, specialty 208, Agroengineering (Master). It is unique in that the training is carried out on the most advanced equipment in the Centre 
for Precision Agriculture, which was created together with the business partners of the university - Horsh, IMC, and others. Today the construction of the landfill of precision agriculture is under way, which will allow training even in winter.

Regional Management within specialty 281, Public Administration. The uniqueness lies in the fact that this is one of the first training programmes in Ukraine for United Territorial Communities (UTC), which is actually related to decentralisation processes in Ukraine. In addition, the curriculum of this programme developed together with the specialists of the Hochschule Weihenstephan-Triesdorf (Bavaria, Germany) and some of the Master's programmes are prepared by the Sumy Regional State Administration.

Administrative Management within specialty 073, Management (Master), and 073 Management (all three levels of higher education). The peculiarity of the Administrative Management Education Programme is that it is taught in four languages (Ukrainian, German, English, and Russian), and, therefore, a significant proportion of students are foreign students. The uniqueness of this programme is that part of the training material is taught by teachers of the Hochschule Weihenstephan-Triesdorf (Bavaria, Germany), as well as the fact that it is accredited by the European Accreditation Agency ASQUIN. In 2018, accreditation was extended until 2021. Another uniqueness is the possibility of obtaining a double degree in Ukrainian and German at the same time.

\section{Qualitative analysis of cooperation with different groups of stakeholders}

Regarding cooperation with stakeholders, the university participates in 27 international projects, cooperates with more than 20 multinational corporations, including Kernel, UkrLendFarming, NCH, John Deere, HORSCH, Case, Nestle.

In particular, together with the leading agricultural holding of Ukraine, Kernel SNAU, there has been developed a curriculum for training and changes have been made to the curriculum, as well as a significant part of the educational process (practical classes, internships) are carried out at the Kernel Group.

Moreover, the university actively cooperates with the Institute of Applied Physics of the National Academy of Science in Ukraine. Experts in technical sciences of the university also actively cooperate with the Centre for Laser Technology of Metals of the Świętokrzyska Polytechnic in Kielce and the Polish Academy of Sciences (Poland). Scientists in the field of agriculture (wheat and potato genetics) actively cooperate with the People's Republic of China. An indicator of significant cooperation is the fact that following the results of the competition of joint Ukrainian-Chinese research projects for 2019-2020, out of 37 projects funded, two projects will be implemented by SNAU scientists. 
It should be noted that scientists of applied areas of research carry out research commissioned by regional companies. Thus, examples of such research for agricultural sciences and veterinary medicine include the following areas:

- study of the selectivity of modern varieties of agricultural crops to microbiological and chemical preparations for Bayer LLC - the agricultural department of the German giant;

- clinical studies of preparations for Ukrzoovetprompostach LLC, Dezsistema LLC, the Termit private firm, Brovapharma LLC;

- improvement in elements of corn hybrids cultivation technology of VorozhbaLatInvest LLC (Agroprosperis Holding);

- improvement in the methods of increasing seed productivity of potato varieties of a selection of SNAU farms: Scientific and Production Household Farm, Elitepotato;

- improving the technology of growing sweet pepper seedlings in closed soil Natur Svit PE;

- scientific and consulting support for growing field crops - for several farms of the Sumy district;

- development of the project on the organisation of the territory of the Sejmskiy regional landscape park.

Technical scientists:

- technologies for drying fuel briquettes from straw using air recirculation;

- improving the technology of utilisation of commercial sunflower waste;

- research on physical and mechanical properties of antifriction coatings formed by the method of electroerosion alloying for TRIZ LTD.

Regional companies also sponsor the development of the university's innovation infrastructure. It is planned annually that 6 graduate students and 1-2 doctoral students will carry out research at the facilities of Hlobino LLC, with which the contract is long-term. In Hlobino LLC on a regular basis there are conducted both student internships and research of graduate students majoring in specialty 204 , Technology of production and processing of livestock products.

In cooperation with the world leader in industrial equipment for pig breeding, Hog Slat is expected to open a training laboratory on pork production technology and mechanisation of production processes in pig breeding next year.

In addition, the classrooms are equipped with the latest equipment from leading foreign and domestic manufacturers of agricultural machinery: Horsh and Losova Machinery.

SNAU's consulting activity is in its early stages. Nevertheless, the university was selected as a partner of the Food and Agriculture Organization of the United Nations (FAO) in the Support to the Development of Agricultural Cooperatives programme 
in Ukraine, under which there were conducted online courses on Economic Cooperation and the organisation of 3 training sessions for representatives of agribusiness, as well as individual consultations.

Together with the University of Applied Sciences of Bern, SNAU acted as the national coordinator of the Sustainable Agriculture Development Programme, which assessed the sustainable development of 37 Ukrainian farms (central, northern and northeastern Ukraine) using the RISE 3.0 method and provided advice on sustainable development.

The business community is also a direct customer of educational programmes and courses, in particular, the agricultural direction with the Kernel Group, the biological and processing direction with the Hlobinsky meat-packing plant LLC.

In specialty 281, Public Administration, under the educational Regional Management programme there have been 2 graduate programmes of specialists in regional management, almost all of whom are leaders or leading specialists in UTC or local authorities. These specialists are trained at the request of the Sumy Regional State Administration.

Sumy National Agrarian University was one of the executors in the development of forecasts on socio-economic and innovative development of the Sumy Region for the period up to 2023. In addition, SNAU scientists take active part in developing strategies for the development of the United Territorial Communities of the Sumy and Chernihiv Regions.

SNAU cooperates with foreign scientists from many countries. Active cooperation is observed with scientists from Poland and Germany, which often results in joint publications. According to the Scopus database, SNAU scientists in collaboration with foreign scientists have published 37 works that are indexed in Scopus. Partner universities include: University of Glasgow (the UK), Uppsala University (Norway), Czech University of Life Sciences Prague (the Czech Republic), Scotland's Rural College (the UK), Universiteit van Amsterdam (the Netherlands), Henan Agricultural University (China), Slovak Academy of Sciences (Slovakia), University of Gdansk (Poland), University of Agriculture, Makurdi (Nigeria), Medical University of Warsaw (Poland), Trakia University (Bulgaria), Università degli Studi di Roma La Sapienza (Italy), Uniwersytet Przyrodniczy we Wrocławiu (Poland), University of Tomase Bati ve Zline (the Czech Republic), Jan Kochanowski University, Kielce (Poland), etc.

In addition, foreign partners are involved in teaching the MBA Agricultural Management course, part of the curriculum which is taught by representatives of the Hochschule Weihenstephan-Triesdorf (Bavaria, Germany). 


\section{Innovation infrastructure of the university}

Sumy National Agrarian University has a Start-up Centre, which by all indications can be attributed with being a business incubator. The main goal of the Start-up Centre is to develop agricultural business education, increase the efficiency of experience exchange, establish business contacts and create conditions for organising own innovative businesses by students, agricultural interns, university graduates, and other stakeholders in the Sumy Region.

The main tasks of this centre are to turn an idea into a business, to help develop projects qualitatively and bring them to the prototype and presentation stage to potential investors. The efficiency of the Start-up Centre may certainly be higher. The project of the SNAU Start-up Centre, entitled Development of environmentally friendly biodegradable containers for hot drinks, took part in the AllUkrainian Innovation Competition and took $2^{\text {nd }}$ place in Economic Innovation contest. International competition University Start-up World Cup 2018 was awarded in the category of Sustainable Development. SNAU has also the Centre for Advanced Training, which offers courses and seminars for professionals from the industry sector of the economy.

The main advantages of the Start-up Centre include the following:

- the possibility of the university to retain talented and bright researchers, because in the absence of basic funding for science today, the university has very little leverage in this aspect;

- raising the level of recognition in the country and abroad, and its belonging to the map of innovative universities;

- accumulation of social capital of communication with people of creative thinking, as well as with the governing bodies of higher education and innovation.

Additionally, the respondents admit that the projects implemented within the Start-up Centre do not bring profit to the university directly.

A major asset of the university is that it has a centre for the sharing of scientific equipment, which includes several laboratories equipped with state-of-the-art research equipment. The university has existing patents and has more than 258 units.

\section{Academic entrepreneurship}

The university pays great attention to the connection between education, science, and practice. The position of the university is based on the fact that an agronomist or zootechnician also needs economic knowledge, so in all specialties there are educational disciplines of economic orientation, including those aimed at 
developing entrepreneurial skills. In fact, the SNAU Start-up Centre acts as a driver of economic entrepreneurship.

Thus, SNAU is a specialised university and occupies a leading position in the academic sector of the Sumy Region, as well as participates in the development of the innovation ecosystem of the region.

The activity of the university correlates with the principles of the Sumy Region Development Strategy until 2020, which means that it tries to meet the business demand for the services provided. But for the most part this applies to the educational activities of the university, which is mainly focused on its efforts (advertising the university, costs associated with admission campaigns, meeting the needs of students, cooperation with internships, potential employers, etc.), which can influence the development of the regional innovation ecosystem of the region.

It should be noted that among the assessed areas of the university's activity its cooperation with regional stakeholders is quite strong, which is gaining momentum: the cowork with small, medium-sized, and large businesses involved in the agricultural sector is active, which is manifested in cooperation on the necessary courses, but at the same time, the university still has the potential for growth in joint research and publishing. There is also cooperation with the Sumy Regional State Administration. The university is open in scientific activity, as evidenced by active cooperation with other research institutions.

Cooperation with stakeholders is not one-sided: the university provides consulting services. However, there is a low return on such activities, which requires a revision of the business model in this area.

As for the innovation infrastructure of the university, it is not sufficiently developed, but is represented by individual elements, or some functions may actually be performed by other structural units, such as the research part.

The university has a successful example of a spinout project. At the same time, SNAU has faced the problem of how to keep scientists who have developed a successful project, which needs further management.

\section{Discussion}

The use of the JRC methodology allowed the authors to study the role of the university in the innovative development of the region by 4 parameters. In particular, it was determined that the activities of the university correlate with the principles of the Sumy Region Development Strategy until 2020, which made it an important component of the region's development. 
The methodology allows the authors to study comprehensively the place and role of the educational institution in regional development. In addition, the advantage of the method used is its unification, and hence the ability to compare the results of research on the role of other universities in the innovative development of regions. This applies both to universities within a region, a country or group of countries.

However, the possibility of further improving the methodology should also be pointed out. In particular, it is advisable to expand the circle of respondents and include other stakeholders: the business community and regional authorities. This allows one to study the contribution of the university to the development of the region better, and secondly, will increase the objectivity of the results.

\section{Conclusion}

Sumy National Agrarian University is a specialised university and occupies a leading position in the academic sector of the Sumy Region, as well as participates in the development of the innovation ecosystem of the region. In particular, the university cooperates with powerful transnational agricultural companies operating in the region and is actively engaged in innovation. In addition, research is regularly conducted in the field of agricultural sciences at the request of the local business community.

At the same time, the analysis allowed the authors to form a number of recommendations for improving the efficiency of innovative activities of the university. Thus, in terms of cooperation with stakeholders, it is advisable to: 1) strengthen its publishing activity, not only with partners from research institutions, but also with business representatives; 2) increase the potential for the impact on the innovation ecosystem of the region through the Alumni Club, which should involve UTC chairmen who are graduates of its Master's programmes (including Regional Management). Thus, it will be easier to influence the development of the innovation ecosystem of the Sumy Region, also the Chernihiv Region and other neighbouring regions participating in various projects.

In terms of strengthening the innovation infrastructure of the university, it is advisable to review the business model of the existing Start-up Centre, the results of which are currently non-profit. Perhaps it makes sense to make it specialised with an emphasis on projects with an agricultural component, and also to position its activity not only for students of SNAU, but also for other inventors in the agrosphere throughout the region. This will increase financial revenues from its activities.

It is advisable to strengthen academic entrepreneurship through the creation of a regional agricultural cluster, involving all relevant stakeholders in the region. 
The promotion of the university's patent activities should also be strengthened. Although the patent portfolio is rich, it is poorly represented in the university's Internet resources, so stakeholders have limited access to this information.

The university should pay attention to knowledge transfer partnership models that aim to encourage the mobility of human capital between the university and local businesses.

In addition, it is necessary to continue the intensive international activities. It is since 2017 that the university has intensified its activities in this direction and there are already the results visible: an increase in the number of foreign students at all educational levels. Universities are increasingly active in a globally competitive market, both in terms of student recruitment and in terms of attracting academic staff. This leads to an increase in international partnerships, and collaboration also affects employees, who are likely to be more mobile internationally if they participate in research projects and training programmes, which may include student exchanges or periods of study abroad.

\section{Acknowledgements}

We would like to thank Chaika Darya, DeputyDirector of the General Directorate for Science and Innovation of the Ministry of Education and Science of Ukraine, Chernyuk Vitaliy, Head of the Expert Group on Integration into the European Research Area, Ihor Taranov, Head of the Expert Group on Innovation Development, and Lykhachova Yulia, State Expert of the Expert Group on Innovation Development.

\section{References}

Audretsch, D.B., Leyden, D.P., \& Link, A.N. (2013). Regional appropriation of universitybased knowledge and technology for economic development. Economic Development Quarterly, 27(1), 56-61.

Benner, M. (2020). Six additional questions about smart specialization: Implications for regional innovation policy 4.0. European Planning Studies, 28(8), 1667-1684.

Brătucu, G., Lixăndroiu, R.C., Constantin, C.P., Tecău, A.S., Chițu, I.B., \& Trifan, A. (2020). Entrepreneurial university: Catalyst for regional sustainable development. Sustainability, 12(10), 4151.

Chelwa, G. (2020). Innovating development strategies in Africa: The role of international, national and regional actors by Landry Signé cambridge. The Journal of Modern African Studies, 58(1), 161-162. 
Ciapetti, L. (2010). Universities as embedded knowledge hubs and the challenge of local development. The us lessons and the Italian case. European Spatial Research and Policy, 16(2), 5-22.

Dettenhofer, M., Doussineau, M., \& Arregui-Pabollet, E. (2019). An analysis of university governance dimensions in academic research and s3 innovation performance. Smart Specialization Strategies and the Role of Entrepreneurial Universities, 153-185.

Eklinder-Frick, J.O., Perna, A., \& Waluszewski, A. (2020). What's smart about smart specialization - a new EU innovation strategy or more of the same? Journal of Business \& Industrial Marketing, 35(12), 1997-2010.

Fioramonti, L. (2013). Round table report: Advancing regional social integration, social protection, and the free movement of people in Southern Africa. Regions and Cohesion, 3(3), 141-145.

Fongwa, N.S., \& Marais, L. (2016). University, knowledge and regional development: Factors affecting knowledge transfer in a developing region. Africa Education Review, 13(3-4), 191-210.

Fongwa, S.N., \& Wangenge-Ouma, G. (2015). University as regional development agent: A counterfactual analysis of an African university. Africa Education Review, 12(4), 533-551.

Frandoloso, M.A., \& Gasparetto Rebelatto, B. (2019). The participatory process of planning social and environmental responsibility at a Brazilian university. International Journal of Sustainability in Higher Education, 20(5), 917-931.

Giyarsih, S.R. (2017). Regional management of areas with indications of urban sprawl in the surrounding areas of Universitas Muhammadiyah, Yogyakarta, Indonesia. Indonesian Journal of Geography, 49(1), 35.

Harloe, M., \& Perry, B. (2004). Universities, localities and regional development: The emergence of the 'mode 2' university? International Journal of Urban and Regional Research, 28(1), 212-223.

Jiang, Z., Chandrasekaran, S., Zhao, G., Liu, J., \& Wang, Y. (2020). Teaching towards Design-Based learning in manufacturing technology Course: Sino - Australia joint undergraduate program. Sustainability, 12(9), 3522.

Ma, J., Zhu, K., Cao, Y., Chen, Q., \& Cheng, X. (2020). An empirical study on the correlation between university discipline and industrial structure in The Guangdong, Hong Kong, and Macao Greater Bay Area. Asian Education and Development Studies, Aheadof-print (Ahead-of-print), 1941.

Marques, P., Morgan, K., Healy, A., \& Vallance, P. (2019). Spaces of novelty: Can universities play a catalytic role in less developed regions? Science and Public Policy, 46(5), 763-771.

Mbah, M., \& Fonchingong, C. (2019). Curating indigenous knowledge and practices for sustainable development: Possibilities for a socio-ecologically-minded university. Sustainability, 11(15), 4244.

Nicholls, S. (2018). Influences on international student choice of Study Destination: Evidence from the United States. Journal of International Students, 8(2), 597-622. 
Pires, A. (1997). Can a strategic project for a university be strategic to regional development? Science and Public Policy, 24(1), 15-20.

Ponsiglione, C., Quinto, I., \& Zollo, G. (2018). Regional innovation systems as complex Adaptive systems: The case of lagging European regions. Sustainability, 10(8), 2862.

Purcell, W.M., Henriksen, H., \& Spengler, J.D. (2019). Universities as the engine of transformational sustainability toward delivering the sustainable development goals. International Journal of Sustainability in Higher Education, 20 (8), 1343-1357.

Roman, M., Varga, H., Cvijanovic, V., \& Reid, A. (2020). Quadruple helix models for sustainable regional innovation: Engaging and facilitating civil society participation. Economies, 8(2), 48.

Saha, N., Saha, T., \& Saha, P. (2019). Smart specialization strategy. Smart Specialization Strategies and the Role of Entrepreneurial Universities, 100-130.

Salama, A.M., Wiedmann, F., Thierstein, A., \& Al Ghatam, W. (2016). knowledge economy as an initiator of sustainable urbanism in emerging metropolises: The case of Doha, Qatar. International Journal of Architectural Research: ArchNet-IJAR, 10(1), 274.

Sozinova, A.A., Nabokikh, A.A., Ryattel, A.V., \& Sanovich, M.A. (2019). Analysis of "underdevelopment whirlpools" as a tool of managing the regional market of education in the conditions of industry 4.0. On the Horizon, 27(3/4), 173-179.

Stebleton, M.J., Diamond, K.K., \& Rost-Banik, C. (2018). Experiences of foreign-born immigrant, undergraduate women at a u.s. institution and influences on career - life planning. Journal of Career Development, 47(1), 11-28.

Tetrevova, L., \& Vlckova, V. (2019). Collaboration between higher education institutions operating in the Czech Republic and the non-academic sphere. European Education, 52(1), 68-79.

Vido, J., \& Nalevanková, P. (2020). IoT (Internet of Things) based technology helps regional farmers improve their agricultural production and effectiveness: Prototype from Technical University in ZVOLEN (Slovakia). Proceedings, 30(1), 77.

Wooltorton, S., Palmer, M., \& Steele, F. (2011). A process for transition to sustainability: Implementation. Australian Journal of Environmental Education, 27(1), 160-174.

Xia, W., Li, B., \& Yin, S. (2020). Identification of influencing factors for sustainable development: Evaluation and management of regional innovation performance in Heilongjiang, China. Sustainability, 12(7), 2739.

Zapp, M., \& Lerch, J.C. (2020). Imagining the world: Conceptions and determinants of internationalization in higher education curricula worldwide. Sociology of Education, 93(4), 372-392. 


\section{Yevheniia Polishchuk}

Doctor of Economic Sciences (2017), PhD in Economics (2009), scholarship of the French government (2014), DAAD (2015, 2017, 2018), scholar internship at École internationale des sciences du traitement de l'information at Cergy (2014), University of Konstanz (2015, 2017, 2018), University of Warsaw and Jagiellonian University in Cracow (2018). Currently, she holds the position of Professor at the Department of Corporative Finance and Controlling, Kyiv National Economic University named after Vadym Hetman, Kyiv, Ukraine. Her scientific interests are connected with problems of smart specialisation, innovations, SMEs development, financing of innovative projects. She has practical experience in the field of SMEs research centre at the UN DP; she worked at the position of innovation manager at the State Finance Institution for Innovations.

e-mail: polishchuk@kneu.edu.ua

ORCID: 0000-0002-6133-910X

\section{Anna Kornyliuk}

$\mathrm{PhD}$ in Economics (2011); scholar internship at TalTech School of Business and Governance (2020); currently, holds the positions of Associate Professor at the Corporative Finance and Controlling Department, Kyiv National Economic University named after Vadym Hetman and Senior Researcher at the Institute for Economics and Forecasting, National Academy of Sciences of Ukraine, Kyiv, Ukraine. Her research interests are connected with problems of smart specialisation, SMEs development, public and corporate debt, banking. She has practical experience as a public governance and finance analyst at Kyiv School of Economics and the Financial and Economic Analysis Office in the Verkhovna Rada of Ukraine. e-mail: anna.kornyliuk@kneu.edu.ua

ORCID: 0000-0001-8713-0681

\section{Alla Ivashchenko}

Doctor of Economic Sciences (2021), PhD in Economics (2011), internship at Ottawa University under funding of Westminster Foundation for Democracy in Ukraine (2018). Currently, she holds the position of Associate Professor at the Corporate Finance and Controlling Department at Kyiv National Economic 
University named after Vadym Hetman (Kyiv, Ukraine). Her scientific interests are focused on such issues as SMEs development and their funding, innovation activity of SMEs, blockchain technology application in the business sphere, smart specialisation. She has practical experience in the field of conducting research in the form of analytical materials as a response to requests of MPs of Ukraine or committees of the Verkhovna Rada of Ukraine at the Financial and Economic Analysis Office in the Verkhovna Rada of Ukraine. She has experience in developing research and scientific projects financed By the Ministry of Education and Science in Ukraine as well as different international funds.

e-mail: alla.ivashchenko@kneu.edu.ua

ORCID: 0000-0002-4599-7137

\section{Yuriy Danko}

Doctor of Economics (2016), PhD of Economics (2011); research internship at the University of Warsaw (2015), University of Georgia (2019). Today he holds the position of Vice-Rector of Sumy National Agrarian University, Sumy, Ukraine. His research interests are related to the problems of marketing and competitiveness in the context of sustainable development.

e-mail: y.danko@snau.edu.ua

ORCID: 0000-0002-9847-1593

\section{Oleh Pasko}

$\mathrm{PhD}$ in Economics, Associate Professor, Head of the Research Coordination Office at Sumy National Agrarian University; research internship at the University of Warsaw and Jagellonian Uiversity in Cracow (2019), University of Applied Sciences Weienstephan-Trisdorf, Trisdorf (Bavaria), Germany (2018). He has experience in international projects of Erasmus (KA2, KA1). Areas of research: globalisation of accounting and auditing; critical research in accounting and auditing; national regulation of accounting and auditing; development and application of the International Financial Reporting Standards and International Standards on Auditing in the context of globalisation of the world economy; research based on capital market accounting (SMBAR), corporate governance.

e-mail: o.pasko@snau.edu.ua

ORCID: 0000-0002-6275-5885 


\title{
Annex 1
}

\section{PROFILE OF THE STUDY UNIVERSITY AND EVALUATION OF ITS IMPACT ON THE DEVELOPMENT OF THE REGIONAL INNOVATIVE ECOSYSTEM}

\author{
BY THE JOINT RESEARCH CENTER METHODOLOGY
}

A list of indicative questions that will be asked to the respondents during the interview

\section{General information about the researched university}

The place of the university in international and domestic rankings

The mission of the university

Supervisory Board of the University

University budget 2015/2019

Number of employees in total in 2015/2019

Number of administrative staff 2015/2019

Number of researchers 2015/2019

Number of students 2015/2019

The share of foreign students studying for a bachelor's degree in 2015/2019

The share of foreign students studying for a master's degree in 2015/2019

Share of foreign students enrolled in the $\mathrm{PhD}$ program 2015/2019

Number of publications 2015/2019

Number of citations 2015/2019

Number of patents 2015/2019

Specialists in which unique areas are trained at the university (max. 5 areas, which levels - bachelor, master, $\mathrm{PhD}$ programme)? What is the reason for this uniqueness? Does this accelerate the demand for educational programmes?

\section{Cooperation with stakeholders}

With which multinational companies does the university have contractual relations, what do these companies specialise in?

Is the university a member of industry clusters?

Does the university cooperate with research centres, institutes, if so, which ones?

Number of joint publications with business representatives, with representatives of research centres and institutes - 2015/2019

Availability of research orders with regional companies (under the agreement)

Do regional organisations sponsor the development of the university's innovation infrastructure?

Existence of joint $\mathrm{PhD}$ programmes ( $\mathrm{PhD}$ industry) with private companies/corporations 
Existence of cooperation with HR departments of small, medium-sized and large business companies.

University consulting: which companies and in what direction are consultations?

Do you involve representatives of the business community in the development of educational programmes?

Is the business community a direct customer of educational programmes or courses?

Does your university offer advanced training courses? Percentage of general educational programmes.

Is the university involved in the activities of the regional state administration of the region in the direction of forming a strategy of innovative development? Are there representatives of the university in the relevant working groups?

If so, in what form?

Availability of information on employment of master's graduates in the region by the relevant specialty

Cooperation with foreign scientists: from which countries?

Cooperation with foreign scientists: number of co-authored publications with foreign scientists.

Are colleagues from foreign universities: countries involved in teaching? Short-term or long-term courses?

Innovative infrastructure of the university

Does the university have elements of the innovation ecosystem (business incubators, hubs, accelerators, technical and science parks, research centres)?

If so, what exactly?

How do you assess their effectiveness?

Are there successful practices for implementing innovative projects? In what areas?

What do these elements of innovation infrastructure provide? Search for funding (local and external funds), search for partners, project promotion, cooperation with policymakers.

What do universities get from the implementation of such projects?

Is there an alumni university club?

Does the university have programmes to stimulate innovative activity of students and teachers by regional business? For example, scholarships, grants, etc.

Does your university have a technology transfer department?

Is there a patent portfolio?

Patents only of scientists of your university, Patents in cooperation with various firms, patents in cooperation with research centres?

Are there business representatives among the teaching staff (in part-time education)

Are there any people involved in the business who are relevant to the disciplines they teach (part-time in business)? 


\section{Development of academic entrepreneurship}

Is there a spin-off company? How many people were employed through these spin-off companies? Are these spin-off companies visible in the development of the region?

Are students involved in creating spin-off companies?

Are educational disciplines for the development of entrepreneurial skills available to students of all specialties?

Proportion of students who underwent internships in regional companies?

Does the university have equipment for research and production of innovative products that can be used by business representatives?

Does the university have the opportunity to raise funds for the implementation of innovative projects?

Does the university's strategy reflect the strategic guidelines of regional development?

How do you assess the university's contribution to the development of regional business infrastructure? 